\title{
In silico screening of alleged miRNAs associated with cell competition: an emerging cellular event in cancer
}

\author{
Manish S Patel ${ }^{1 *}$, Bhavesh V Antala ${ }^{1}$, Neeta Shrivastava ${ }^{1,2}$ \\ From International Conference on Human Genetics and 39th Annual Meeting of the Indian Society of \\ Human Genetics (ISHG) \\ Ahmadabad, India. 23-25 January 2013
}

\section{Background}

Cell competition is identified as a crucial phenomenon for various conditions like cancer, aging and organ development. MicroRNAs (miRNAs) may play an important role in regulation of expression of genes involved in cell competition at the post-transcriptional level. In silico screening of miRNAs involved in a cell competition is an effort to identify potential miRNAs and to reduce, economize and expedite experimental work. In the present study we have identified miRNAs of Drosophila genome involved in a cell competition using in silico screening strategy.

\section{Material and methods}

We used four steps of in silico (i) Selection of cell competition related genes of Drosophila genome through literature survey; (ii) Identification of miRNAs that target selected cell competition-related genes; (iii) Sequence conservation analysis of identified miRNAs with Human genome; (iv) Identification of genomic location of that Drosophila miRNAs and exploration of their expression profiles in tissues by use of host gene expression profile.

\section{Results and conclusions}

In this study we have identified seven potential Drosophila miRNAs that are most probably involved in cell competition. Human homologs of these seven potential miRNAs may be very important in cell competition related diseases like cancer. Proof of this concept will be established with wet lab experimentation to reassert the role of miRNAs in cell competition.

\footnotetext{
* Correspondence: patel_manish22002@yahoo.com

'Department of Biotechnology, National Institute of Pharmaceutical Education and Research (NIPER)-Ahmedabad, Ahmedabad-380054, Gujarat, India

Full list of author information is available at the end of the article
}

\section{Authors' details}

'Department of Biotechnology, National Institute of Pharmaceutical Education and Research (NIPER)-Ahmedabad, Ahmedabad-380054, Gujarat, India. ${ }^{2}$ Department of Pharmacognosy and Phytochemistry, B. V. Patel Pharmaceutical Education and Research Development (PERD) Centre, Ahmedabad-380054, Gujarat, India.

Published: 21 January 2014

doi:10.1186/1755-8166-7-S1-P6

Cite this article as: Patel et al: In silico screening of alleged miRNAs associated with cell competition: an emerging cellular event in cancer. Molecular Cytogenetics 2014 7(Suppl 1):P6.
Submit your next manuscript to BioMed Central and take full advantage of:

- Convenient online submission

- Thorough peer review

- No space constraints or color figure charges

- Immediate publication on acceptance

- Inclusion in PubMed, CAS, Scopus and Google Scholar

- Research which is freely available for redistribution

\section{() Biomed Central}

